\title{
Maria Kuglerova
}

Faculty “Artes Liberales”

University of Warsaw

\section{"Ay, But Droma Pkhirdyom": The Gypsy and the Road}

\section{(Self-Identity in Soviet and Post-Soviet Gypsy Literature in the Russian Cultural and Political Context)}

\begin{abstract}
The Gypsies have always been a peculiar minority in Russia. On one hand, the Russians admired Gypsies' vagrancy and desire for freedom. The Gypsies were a kind of an alter-ego of the Russians' - as they wished to be, but dared not. On the other hand, the Gypsies even in relatively liberal czarist times were treated as the second-rate people, not mentioning the soviet deportations. The Gypsy wandering was especially irritating, so the authorities always tried to settle them down. From the Gypsies' side the attitude (the strict opposition Gadjo/Roma and at the same time the phenomenon of the "choral" settled Gypsies who connected Russian and Gypsy cultures) was ambiguous, too. It shows the main feature of Gypsy identity - the desire for wandering, the dependence - but only on the road, and the dual attitude to this feature from the side of the Russian majority. This feature and the ambiguous attitude towards it one can define as the crucial feature of the Soviet and Post-Soviet Gypsy literature. By 1938 (before the supporting of the national minorities stopped) in Soviet Gypsy literature existed two main directions in the narration: the narration about the evil capitalistic past (the exploitation of the "choral" Gypsies, who were devoid of the road by Russians - M.Iljinsko's stories) and the depicting of the brave

This is an Open Access article distributed under the terms of the Creative Commons Attribution 3.0 PL License (creativecommons.org/licenses/by/3.0/pl/), which permits redistribution, commercial and non-commercial, provided that the article is properly cited. (C) The Author(s), 2014

Publisher: Institute of Slavic Studies, Polish Academy of Sciences

Editor in chief: Jolanta Sujecka

Conception and academic editing of this issue: Maciej Falski
\end{abstract}


Soviet reality - when the Gypsies are happy to work and to be settled in the kolkhozes (M.Bezludzko's poems). This image of the new Soviet Gypsy is rooted in the image of the vagrancy (through its' denial for Soviet epoch and its' glorification for czarist times), as the detailed analysis of the texts shows.

Key words: Gypsies; Gypsy literature; Soviet Union; Gypsy identity; road

Tntil recently the Gypsy people were the most famous nomadic "ahistorical" (Lubecka 2005: 156) people in the world without their "home state" (Barany 2002: 2). Although nowadays only 4 per cent of the European Gypsy population is nomadic (Джурич 1999: 4), the Gypsy minority is still considered to be marginal, and this is also because of their nomadic past (Barany 2002: 2). Thus, the image of the road is a crucial part of the Gypsy identity, which is reflected in Gypsy literary creation, too. In this article the definition of "the road" contains a whole wide range of meanings: it means not only the change of location in space, it also means the image of Gypsy vagrancy, nomadic life, existence in the Gypsy camp and the Gypsy way of organizing space, which is presented in Gypsy fiction.

I will concentrate on the Soviet Gypsy literature which briefly flourished in the years 1926-1938. The survey of some modern Gypsy works will serve to demonstrate the changes in Gypsy self-identity in the context of the article's agenda.

The Gypsy "russka roma" minority is perhaps the most significant minority in the Russian cultural context, and, in turn, this minority was under the biggest Russian cultural influence. This mutual connection, which started in the 18th century, led to "the creation of professional Gypsy choirs, which have huge importance for Russian culture" (Махотина 2012). The image of the Gypsy in classic Russian literature was a symbol of a freedom-loving, independent man - a sort of Russian alter ego who is free, as the Russians always wished to be but dared not. Pushkin, Leskov, Turgenev, Tolstoy, Gorky and many others depicted the Gypsies in their works. However, this "sympathy for the Gypsy" was a part of the Russian perception of their identity ${ }^{2}$, and very often it was full of inaccuracies and clichés (Banaszkiewicz 2008: 147; Деметер, Бессонов, Кутенков 2000: 53-68). In spite of their great influence on Russian culture, the Gypsies, being illiterate people, remained a "silent minority" and didn't have their own voice.

Things changed after the establishment of the communist regime, in the trend of Soviet minority politics, when the Soviet government started to

\footnotetext{
1 In this article, when talking about Russian Gypsies I concentrate on the "russka roma" ethnical group which has had a considerable influence on Russian mentality and culture (Махотина 2008). 2 About "Russian literature as a part of the imperial Russian project" see: Thompson 2000: 33.
} 
support the development of the minority's literature ${ }^{3}$. However, analysis of Soviet Gypsy literature will show that, actually, this literature was under the communist regime's strict ideological control. Still, it was the first possibility for the Russian Gypsies to speak up about themselves ${ }^{4}$.

Before starting an analysis of Soviet Gypsy fiction, it is necessary to say something about its system of narration in comparison to modern Gypsy literature. As Cecil Kovachasie (Ковачази 2009) states when considering post-Soviet Gypsy literature, it is closely connected to Gypsy folklore, which is why poems, short poems and songs prevail in the genre system of modern Gypsy literature. Memoirs as a genre can also be found among the works of modern Gypsy authors. The short story is a less popular genre, and the novel is quite a rare phenomenon in modern Gypsy literature. On the other hand, short stories and poetry prevailed in Soviet Gypsy literature as well. Whereas Russian Gypsy literature of the end of the 20th century is connected to its Gypsy folklore roots, the Gypsy literature of the socialist realism period tried to get close to the Russian realistic tradition of narration ${ }^{5}$ which was inherited from 19th-century Russian literature.

On the other hand, this new Soviet Gypsy literature's direction towards the literary tradition of narration (and moving away from the folklore tradition $^{6}$ ) corresponds to the historical and cultural circumstances. The lack of a written language, the lack of a literary language standard, authors who were raised and educated under the traditional Russian cultural influence ${ }^{7}$ (Ivan Rom-Lebedev, one of the founders of the Romen theatre, recalls in his memoirs that he hardly knew any Gypsy words: his native language, spoken at home, was Russian (Ром-Лебедев 1990: 15)), the flourishing of socialist

\footnotetext{
3 About the activities of the Soviet authorities regarding the "Gypsy question" see: Деметер... 2000: 196-213.

4 About the simultaneous development of Soviet Gypsy literature and deportations and persecution of the Russian Gypsies see: Бессонов 2002.

5 That's why the prose genre was so popular in Soviet Gypsy literature.

6 In Soviet Russian literature of the 1910s and 1920s, invoking the traditions of the skaz was widespread: such a revival of traditional folk narration (started by N. Gogol and N. Leskov in the 19th century)can be found, for example, in M. Zoschenko's, A. M. Remizov's, I. Babel's works. The skaz itself can be defined as the emancipation of literature from the total influence of the written language, a new way of introducing the word into literature by means of imitating human intonation, articulation, voice, facial expression and so on (Os'mukhina 2007: 236). See also two crucial articles by Mikhail Eykhenbaum: Иллюзия сказа (1918); Как сделана «Шинель» Гоголя (1919) (accessed on the Internet). Anyway, Soviet Gypsy authors of this period generally stayed away from this revived tradition.

7 The authors of the monograph История цзыган - новый взгляд state that the leading figures of Gypsy culture in the 20th century had obtained an education thanks to the Tsarist policy towards the Gypsies. The next conclusion is that the Tsarist policy towards the Gypsies was quite friendly, which absolutely does not correspond to the reality (Деметер... 2000: 199).
} 
realism literature in the Russian language ${ }^{8}$ and, finally (and perhaps most importantly), the ideological pressure and control of the new Bolshevik authorities - all these circumstances led to the emergence of Soviet Gypsy literature within the socialist realism trend.

To demonstrate the peculiar artistic and ideological features of Soviet Gypsy literature in the 1920s and 1930s, I have chosen a poem by Michail Bezludzko and some short stories by Michail Il'insko9.

The most significant of the short stories written by M.Il'insko seems to be Ружэнька (Ильинско, Ром-Лебедев 1938), the tragic story of the moral lapse and suicide of a Gypsy girl who was taken from the Gypsy camp to the Gypsy choir in the capital, and was depraved by a rich Russian barin. This little masterpiece of new-born Gypsy literature constitutes a certain opposition to two other stories by Il'nsko - Бори (Ильинско, Ром-Лебедев 1938) and Бурда (Ильинско, Ром-Лебедев 1938). This opposition becomes quite clear when it is analysed in the context of the devices of socialist realism and the concept of the road, which is crucial in Gypsy culture (and remained crucial in the narration of Soviet Gypsy literature). But first it is necessary to show some peculiarities of these texts in connection with the topic of the article.

The importance of the image of the road in early Soviet Gypsy literature is connected with the role of depicting the "old life" in these works. As the realistic and even naturalistic depicting of the "old life" was a typical device in socialist realism texts ${ }^{10}$, it had its place in Soviet Gypsy prose, too. However, it was not only about depicting the "past life" in dark colours (and these colours were not always dark, as it will be demonstrated).

The reader can guess that Soviet Gypsy writers (A.V. Germano, M. Il'insko, M. Polyakova, O. Pankova, M. Bezludzko and others), the young growth of the new Gypsy intelligentsia, believed that the only way for the Gypsies to overcome their marginal position in this new world was to join in the formation of a new Soviet Gypsy identity (which was associated with the whole process of the formation of homo sovieticus - Barany 2002: 30). These people were quite sincere in their wish to show the Gypsy camp life with all its disadvantages and backwardness. Still, it looked like the

\footnotetext{
8 As researchers of socialist realism literature state, the authorship of the term sotsialisticheskiy realizm is ascribed to Maxim Gorky, but it belongs rather to Soviet politics, for in the late 1920s there already appeared documents speaking of the necessity for a new Soviet artistic method (Куренная 1995: 7).

9 The surnames of M.Bezludzko and M.Il'insko are spelled in the Gypsy version, not in Russian - Bezludzkiy, Il'inksiy (which is also common in the literature).

10 The "old world" was portrayed as being worse, the "new world" looked better - it might not exist yet in real life, but it inevitably would, and the readers of such literature must aspire to this ideal (Гугнин 1995: 79). That is one of the main characteristics of socialist realism literature.
} 
Gypsy identity could not let them go ${ }^{11}$. A sentimental feeling towards this "backward," "dirty," "oppressed" and "not progressive" "old life" can be seen in these texts.

Thus, stuck between having to demonstrate the "old life's" horrors, as socialist realism required, and their feeling of Gypsy identity, Gypsy authors chose for their works the chronological opposition "tsarist times new times". On the fringes of this opposition there functions the concept of the road, organizing the artistic and ideological space of these texts. The interesting thing about the ideological space of Il'insko's stories and Bezludzko's poem, where our analysis should begin, is that the source of this ideology, connected with the image of the road and vagrancy, is gender.

Works on Gypsy traditions mostly describe the subordinate position of Gypsy women in the camp (Деметер... 2000: 61-63; Lubecka 2005: 247; Nowicka-Rusek 2008: 41; Mirga 1994: 17-21; Ром-Лебедев 1990: 170). Gypsy women's position of absolute subordination in the camp ${ }^{12}$ and, at the same time, their leading role in running the family, demanded certain features of character: boldness, independence, quick wit (Деметер... 2000: 61). Gypsy women are in touch with the Gadjo's world, just like men are.

Perhaps this uniqueness of the Gypsy female character was the reason why Gypsy writers devoted so much attention to the heroines in their texts. The Gypsy female characters in some of Il'insko's stories and in the poem by Bezludzko embody the new Gypsy ideal: they are brave, progressive, ready to break with the vagrant "old life", to break the fetters of family life, to leave their tyrannical husband and mother-in-law (all vagrants in the fields with their camps) and to settle down in kolkhozes and study at rabfaks. In these texts it is only a woman who can build "a brave new world", and the more she was humiliated and subordinate in the camp, the better the new life waiting for her now, in communism, in the "new times"13.

Nevertheless, this is only one side of the Gypsy woman's character in Soviet Gypsy literature. The images of women who are emancipated or are ready to become emancipated dwell only in the chronological space of the

\footnotetext{
11 This did not concern only the Gypsy intelligentsia. In his book of memoirs I. Rom-Lebedev compares the moods of his father, the famous conductor of the Gypsy choir in Moscow, and the feelings of the Gypsy kolkhoznitsa - both people who had settled and who suffered in spring when the cranes were flying back - which means the time of going out into the fields (РомЛебедев 1990: 103, 180).

12 About the Gypsy system of mageripen, pekelimos (magirdo), which means profanation and in which the woman plays a substantial role, see, for example, Деметер... 2000: 63.

13 According to the words of the International: Мы наш, мы новый мир построим,/ Кто был ничем, / Тот станет всем (We'll build our new world,/The one who was nobody,/Will become everything).
} 
"new times", and if they are not free yet, they will be free tomorrow. The other type of woman is placed in the chronological space of the "tsarist times", and the change of the times leads to a complete change of the role played by the image of the road in all these texts.

In the short story Ружэнька, life in "tsarist times" is shown as completely evil. As Michał Głowiński states, "the socialist realism critics eagerly talked about pouring new wine into old wineskins" (Głowiński 1992: 14). That was how the "new wine" of Gypsy socialist realism literature was poured into the "wineskin" of Russian "critical realism". Showing the hopelessness of such a life was well within the "critical realism" trend (the tradition of the "little people" and their miserable life in Russian literature), but the purpose was different, as explained earlier.

The "old world" is absolutely bad (in the tradition of the "critical realism" approach), it is defective, it can only be demolished to make room for the new one (and this is the "new wine" of socialist realism). But in the story Ружэнька not even the distant shining of the "new world" is present. This creates the perfect tragedy, the hopeless intonation of the narration.

In Ружэнька the sphere of camp life (and nomadic life as such) is first demonstrated as poor, hopeless and marginal. The picture of typical camp life is shown through the father of the heroine and the heroine herself:

Сыр-то кэ бельвель сыс бэшто о Тэля кэ пэ дрэ шатра. Шутькирдя пашыл яг мэлало патаво. Э чяй Ружэнька, сыс бэшты прэ вэдра, чингирдя пхувитка тэ бакраны э ярмяса дрэ пири. Тэля дужакирдя э ромня гавэстыр, коли янэла котэра маро ${ }^{14}$.

The image of the idle proud "old Gypsy", who exploits women and is absolutely useless himself, is also present, for example, in Pankova's poem "Ростасадо джиибен" (The Broken Life). In a very realistic way Il'insko, who knew the details of Gypsy society very well, shows the tradition of Gypsy camp life in which a man (rom) was the perfect master of his women - his wife, his sister, his daughter-in-law and so on. Metaphorically, in Ружэнька this absolute male power is connected to the nomadic Gypsy tradition.

In this story, life in the camp is divided into two parts: one is the "great" nomadic life (going out into the fields in the spring, moving from one place of stay to another and other displays of vagrancy in the "big world"), which belongs to the male. When turning down the poor orphan Vanti who asked for his daughter's hand, Telya speaks proudly of his "huge" clan which is widely spread all over the earth:

14 One evening Telya was sitting near his tent. His was drying his dirty puttees over the fire. His daughter Ruzhenka, sitting on a bucket, was dicing potatoes, mutton and cabbage into the pot. Telya was waiting for his wife to come back from the village bringing some bread. 
Мирэ пиродатэ кя буглы вурма сы, тэ сарэ дживэна пэскирэ кхэрэнца дро баро форо, а ёв злыдня сыс сусветно, на одорик чёроро пэскиро муй банькирла ${ }^{15}$.

The clan system, next to the nomadic life, is another way for the male Gypsy to conquer the outer world. But there is also a "little" space of the nomadic life which belongs to the women. In Ружэнькa this space is connected to the village. The Gypsy women roam the villages to get some food for their children and lazy husbands. This occupation is strictly denounced by the "choral" Gypsies from Moscow:

Явела уже лакэ тэ мирэл э подья пиро гава гонэса тэ тэ зрандэл пэскирэ кхэра ${ }^{16}$.

- Тукэ трэби фэлдытконэ тэрнэ чявэс, тэ выджяс пал лэстэ палором. Тэ лэса подя пиро гава тэ марэс, - холямэс пхэндя Худара ${ }^{17}$.

The village in Ружэнька is a space of no motion, it's still and lifeless, and it is almost as marginal as the Gypsy camp. Kind but stupid and backward Russian peasants inhabit this space. Their stupidity is shown vividly in the story Бурда, when the Gypsy Matikha gets money out of a credulous peasant woman. This peasant slowness and credulity is a portrayal of the exploitation system of the "old world". It also chains the Gypsies to their traditional vagrant life and does not motivate them to change it.

But absolute evil hides in the city, baro foro Moscow. In comparison to the works of socialist realism, in which Moscow represents the sacrum (Щукин 1993: 26), a centre, a final aim for all the workers and the kolkhozniks (readers need to remember that such an approach is only possible in the chronology of the "new times"), in the wrong "old world" of Ружэнька there is no place for sacrum. In Ружэнька the Gypsies' settled life in the city is much worse than the poverty and lawlessness of the camp life in the field. Life without motion in this case means easy money as a result of exploitation (and not honest work in a factory or kolkhoz). The Gadjos, Russian rich raya (masters) corrupt the Gypsies with money, separate them from their nomadic kin, and this is a source of hatred between Gypsies from the city and nomadic Gypsies ${ }^{18}$ :

\footnotetext{
15 My clan is widely spread all over the world, and all of them are living in their own houses in the capital, and he is a scamp, it is not this ragamuffin's cup of tea.

16 It's enough for her to wear out her skirt in the villages and to injure her legs.

17 "You need a 'field' young guy to marry. You will wear out your skirt in the villages", Khudara said angrily.

18 As I.Rom-Lebedev testifies in his memoirs, this mutual hostility between the "field" and the "choral" Gypsies was a reality: "The Moscow choral Gypsies had an unfriendly attitude towards the camp Gypsies, and the nomadic Gypsies called the choral Gypsies 'lickspittles"' (РомЛебедев 1990: 92).
} 
Сыр тумэ сан заглуждёна фэлдытка шынга, тэ и мэрна лэнца ${ }^{19}$.

- Адалэ фэлдытка кэ саро дотошна сы! - пирибандимэ кэ ёнэ пхэндя грубо пэса дирижороскири ромны. ${ }^{20}$

Night life without any motion (except moving between the spaces of the restaurants and the luxury hotels of the big city) is the essence of city existence. Ruzhenka is absorbed by this male world of exploitation (including sexual exploitation), this motionless life of the Russian raya. The illusion of motion between the restaurants and the hotels, even riding in her own $\operatorname{car}^{21}$ : Пирдал мардо зашуминдя пашыл кхэр о автомобилё. Взгыя дрэ штубба розуриды э Ружа ${ }^{22}$ - means her immersion into this motionless living, her moral lapse and simultaneously her escape from reality into dreams. Ruzhenka's dreams are a space of illusive motion, too. She dreams about eloping with her lover Vanti:

Ружэнька пхарэс дыя гондя и дыя дума мэнькаса: “Фэдыр бы тэ унашав палэ Вантистэ... Подарандыём мэ, со о дад э даса прокэрна ман арманя. А уж акана мэ и на мол тэ дыкхав прэ лэстэ пэскирэ малалэ якхэнца"23.

The decision to escape planted in her mind is finally realized in her suicide. The only way for her to move, to escape from this world, is the way down - to death. As it will also be demonstrated in the analysis of Bezludzko's poem Штар пшала (Four Brothers), any motion directed down means death (male death) in these texts. Thus, even in her death Ruzhenka cannot break free from the rules of the male world, no matter whether it is the traditional nomadic Gypsy or the motionless Gadjo world:

На змэки буглэс откэрдэ якха э пхурэстыр э Ружэнька гыя тэ кхэлэл. Дро кхэлыбэн ухтылдя ёй скаминдэстыр стэкла э бравинтаса, екхатыр ла выпия и тэрдыя пашыл фэнштра... - - Радынэпэ, со киндян пал пэскирэ погана, обчидэ ратэса ловэ, миро трупо. Нэ ило миро ту на киндян, полыян? - э Ружэнька чюрдыя стэкла дро шэро пхурэскэ... Сыр будто балваляса подухтылдя ла, локхэдыр чириклэстыр выурняндыя э Ружэнька палэ фэнштра ${ }^{24}$.

\footnotetext{
19 So as you are the cursed field demons, die together with them [Khudara's words].

20 “These field [Gypsies] are pushy in everything!", said the conductor's fat wife, bent over them.

21 Moving using different modes of transport (horses, cars and so on) is part of the male world. Gypsy women generally walked on foot.

${ }^{22}$ In an hour one could hear the noise of a car. All dressed up, Ruzha came along.

23 Ruzhenka, sighing heavily, had agonizing thoughts: "It would be better to run away with Vanti... I was afraid to be cursed by my father and mother. And now I don't dare look at him with my dirty eyes".

${ }^{24}$ Staring with eyes wide open at the old man's face, Ruzhenka started to dance. Dancing she
} 
Another type of chronological borders which can be defined as the "new times" is represented in two other short stories by Il'insko from the book Роспхэныбэна тэ патриня - Бори (Daughter-in-Law) and Бурда, and in the poem Штар пшала written by Bezludzko. What drives the plot of the two stories is the image of the horse, the Gypsies'main mode of transport, with the help of which they carry on their nomadic way of life. The humorous story Бурда starts in a Soviet clinic, where one of the Gypsies tells the story of Burda. His narration contains comic (and at the same time didactic) pictures from the "old life": the Gypsy Burda was such a drinker that he drank away everything he had and his horse died, so his family had to drag the horse-drawn wagon by themselves:

И адякэ уж Матиха чяворэнца мэнчисалыя э Бурдастыр, тэ и кокоро ёв хачия э мортвалятыр, а адай сыр про грэхо, лэ тэ мурдёв лэскиро грай, цыпо остатно, вокурат кэ вэсна... Дуй тыкнинька чяворэ бэштэ сыс про урдэн, а дуй побарыдыр прастандынэ палал палэ Матихатэ, сави сарэ зорьятыр поможындя э палуестыр тэ тырдэл урдэн ${ }^{25}$.

With the help of this pathetic scene the narrator creates the image of the "old life" in the camps, connected with male domination, alcoholism and violence. The continuation of the plot is again associated with the image of the horse: Burda bought a horse (with his wife's money) and lost it through drinking. His desperate wife tried to cure him using magic, but nothing helped. At the end of the story it turns out that the storyteller is Burda himself, who stopped drinking and whom Soviet rule gave almost eternal life:

- Нэ со пхэндя састякирибнари? - пучья лэстыр мануш дро парно халато.

- Пхэндя, со мэ продживава бутыр шэл бэршэндыр ${ }^{26}$.

The story Бори, on the other hand, is dramatic: the reader can learn about the conflict between feelings and duty, which is quite a classic conflict. A true heroine of socialist realism literature, the Gypsy Lushka finds herself having to make a choice: to stay in the camp with her husband

grabbed the glass of vodka from the table, drank it in one gulp and found herself near the window... "Be glad to have bought my body with your dirty bloody money. But you haven't bought my heart, do you understand?", Ruzhenka threw the glass at the old man's head... As if she was gone with the wind, easier than a bird she flew away through the window.

${ }_{25}$ Matikha and the children suffered so much because of Burda, and he himself was perishing because of vodka, and by a stroke of bad luck their horse fell, the last jade, right in the spring... The two younger kids sat in the wagon while the two elder ones from behind, with all their strength, helped Matikha to drag the wagon.

26 "Well, what did the doctor say?", a man in a white overall asked him.

"He said that I would live more than a hundred years". 
Fynku, whom she loves, and with his cruel parents and to live the nomadic life, or to leave them and this backward life and to start a new life, settling down in a kolkhoz.

In the beginning of the story there appears the poor Gypsy Shshjodra, who goes to join the kolkhoz together with his old horse Syvinko. The image of the horse and its role in the development of the plot is quite different than in the story Бурда. Just as in Бурда the horse was a sign of the "old world", one of the links in the chain that ties the Gypsies to their nomadic life (with all the bad habits of that life), so in Бори the horse belongs to the new life. The horse is a symbol of socialist work now. Such a sudden switch of meanings can be explained with the change of the space this image belongs to: in Бурдa the horse belongs to the camp and symbolizes the nomadic life, and in Бори the horse (which even gets its own name - Syvinko, and is depicted as an intelligent creature, in comparison to the nameless and dumb camp horses) is already a kolkhoz horse:

Сывинько пирилыджия канэнца, пришупдяпэ, со ракирдя о хулай. - Окэ, сыго яваса дро колхозо, ту подуминэ, дро амаро романо колхозо! Шшёдра почиладя Сывинькона пирэ мэн. - Ласа буты тэ кэрас, задживаса бахталэс. Ту лэса э джёв тэ хас, а мэ ярми про балычяно мас кэрады. Эх, лачё джиибэн явэла! ${ }^{27}$

Shshjodra's way to the kolkhoz introduces the image of the "road to the new life" to the story, the road Lushka is also supposed to take. On his way to the kolkhoz Shshjodra made a detour to the Gypsy camp. The writer places Shshjodra in a situation of temptation by the "old life" (he honourably passes this test and goes on his way).

It is quite symbolic that night falling in the fields made Shshjodra go to the Gypsy camp. The night, the darkness (kalypen, a word which appears with great frequency in the story) to which the camp belongs - this is the introduction of the backwardness which possesses the minds of the "field" Gypsies, as yet untouched by the influence of communism: "Эx, дикарья, дикарья", - дивисалья ёв ${ }^{28}$.

Fynku's evil parents are the personification of the "dark forces". His mother, Lushka's mother-in-law, according to the Gypsy and Russian folklore tradition, is called the "snake". The father-in-law chains Lushka to

\footnotetext{
27 Syvinko pricked up its ears, hearing what the master was saying.

"So, soon we'll be at the kolkhoz, just think, in our Gypsy kolkhoz!".Shshjodra stroked Syvinko's neck.

"We'll work, we'll have a happy life. You will eat oats, and I'll have soup of pig. Eh, it will be a good life!".

28 "Eh, savages, savages", he thought [Shshjodra]
} 
the traditional camp life and makes her roam the villages, full of unhappiness and bad luck:

Прэ латэ и о муй бибахтало, тэ розвиинэ ла балваляса пиро щукэ, калэ вэша. Саро дывэс жыко само калы рат псирла, тэ марла подя пиро гава ${ }^{29}$.

The scene when Lushka secretly leaves the camp demonstrates her hesitation and the attraction of the still powerful "old world", but the call of the new life turns out to be stronger: Прогыи набутка гыя ко дром Лушка тэрдыя. Подыкхья про шатры тэ пхарэс дыя лондя, учёрдяпэ дро кальипэн ${ }^{30}$.

The road Lushka and Shshjodra travel is different from the old Gypsies' roads. This road is the only one, compared to the multiplicity of the Gypsies' roads, and this is Lenin's road (the image of Lenin's road also appears in Bezludzko's poem Штар пшала.). This is a road from which one cannot turn back and the "dark forces" are powerless in the realm of the new world that is being built. Fynku and his parents' attempt to kidnap Lushka from the kolkhoz fails. Lushka riding the horse at the end means complete deliverance from the fetters of the nomadic life ${ }^{31}$ and Lushka becoming a conscientious kolkhoznitsa; she has stayed loyal to her husband, but the duty of socialist work and travelling along Lenin's road is more important:

Ко урдэн Фынкускиро подгыя уклисто прэ калэ грэстэ Лушка, нэ на згыи грэстыр ёй тихэс пхэндя Фынкускэ:

- Мэ джином, со ту камэса ман. И ту джинэс, со и мэ тут камам, нэ тэ дживав адякэ, сыр джиндям жыко адая пора, мэ на можынава... мэ тут лава тэ дужакира... - доракирдя э Лушка тэ крэнтэс обрискирдя э грэс тэ гыя дрэ строна ко колхозо ${ }^{32}$.

In Bezludzko's poem Штар пшала (Bezludzko 1931) the reader can find the same artistic device of socialist realism as that found in Il'insko's works. The image system of the poem is divided into two parts: the first one presents the male, vagrant, asocial life led by the four brothers, and the second depicts the conscientious working life of the sisters.

\footnotetext{
29 She has an unhappy face, let the winds blow her in the dry black forests. All day long until the dark night she roams and wears out her skirt in the villages.

${ }^{30}$ Lushka walked a little towards the road and stopped. She looked back at the tents and sighed heavily, disappeared in the darkness.

31 In comparison to Ruzhenka, whose riding in a car meant total absorption by the men's world, Lushka's riding the horse signifies total emancipation from the prejudices of the camp life in the glory of the new working life.

32 Lushka rode up to Fynku's wagon on a black horse, but sitting on the horse she said quietly:

"I know that you love me. And you know that I love you, too, but I can't live anymore the way I lived before... I'll be waiting for you..., added Lushka and turned the horse towards the kolkhoz.
} 
The road of crime chosen by three brothers led them to the ground (here, again, there appears the motif of moving down, which is the result of Gypsy wandering and living "the old way"):

Дай сдыкхья мангэ дро якха,

А пиро муй ясва прастана:

- “Сарэ трин... мро чяворо, гара...

Пашлэ дрэ пхув... тырэ пшала”"

The Gypsy roads are multiple, and one can easily lose oneself travelling them without proper ideological training: Мири пхури дай. Сомас и мә дро старибэн/ Заплэндыньдёмпэ дро бут дрома... ${ }^{34}$

This is a symbol of dangerous Gypsy freedom, which can ultimately only lead to condemnation and to death. In Bezludzko's poem the difference between the vagrant life and the settled life is equated with the difference between death and life - that is how following the politics of the communist party gains an ontological dimension. The Gypsy brothers who roamed the roads are dead now, and the hero of the poem says about himself: Umap пшала исыс амэн/ Екхджино ачёмпэ мэ дро кхэр ${ }^{35}$.

The sisters of the poem's main hero, as settled Gypsies, have chosen the one and only right road:

“Миша, мэ про курсы сыклёвава, -

Гана пхэн мири ракирла, -

“Экзамено прэ шоферостэ сыго здава,

А Лёля про рабфако штэто дужакирла.

- Клаша и э Люба сыклёна про рабфаки... ${ }^{36}$

The road of the real new life, which will lead the Gypsies to heaven on earth (e.g. to the kolkhozes, factories and other embodiments of the working life), is Lenin's road:

Кана рома парувэна прэ кхэра пэскири шатры,

Парувэна фэлда про гаджитко хулаибэн.

Мэ галыём нэво джиибэ,

И на змаравапэ, кана Ленинсконэ дромэстыр ${ }^{37}$.

33 The mother looked at me with her eyes,/And a tear ran down her face:/“All three...my boy, long time.../Lie in the ground... Your brothers".

34 My old mother. I was lost in criminality/On many roads...

35 We were four brothers, /It's only me who stayed at home.

36 "Misha, I study at kursy, -/Says my sister Gana,-/I will take a driving test soon,/And Lyolya is waiting for a place at the rabfak. /-Klasha and Ljuba study at the rabfak..."

37 "Now the Gypsies change their tents for houses,/Change the fields for the Gadjo life... I knew 

road.

- and leading a settled life is the only way for the Gypsies to follow this

As opposed to Soviet Gypsy literature, modern Gypsy literature is devoid of any element of propaganda, for, in the words of the scholar: "the paternalistic encouragement and strict state control of the end of the 1920s-1930s, the absolute prohibition of the late 1930s to early1950s, the bureaucratic vigilance of the 1950s-1980s have been replaced with total indifference. It is now about financial problems instead of political and ideological ones" (Калинин, Русаков).

Modern Gypsy authors try to revive the past Gypsy mentality in their works, and this identity's rejection is also related to the image of the road. Modern Russian Gypsy authors are educated and erudite people who have a background in 20th-century literature and culture, and their works cannot be defined as "amateur and naive" anymore (Махотина 2011).

Modern Gypsy literature consciously reconstructs the Gypsy identity, considers what it means to be a Gypsy, what the elements of this identity are. Two main approaches to this subject can be identified in Gypsy literary works. The first one is philosophical, when the author reflects on the features of Gypsy culture in the light of world culture and history (Georgi N. Cvetkov, Valdemar Kalinin). The second trend involves sketches from everyday Gypsy life (Lera Janysheva, Alexey Sinitsyn and others), and it will not be considered in this article.

Georgi N.Cvetkov ruminates on the road as the fundamental element of Gypsy identity, but as an element belonging to the past. That is the paradox of the modern Gypsy consciousness - it can be identified with a tradition that has almost disappeared but is still strong in people's minds. The picture of nomadic Gypsy life (with romantic overtones) is presented in all of Cvetkov's poems:

Мэ на ладжьяв-пэ, кэ сом ром.

Миро вурдон урнял по дром.

Дживас амэ сыр чириклья... ${ }^{38}$ (Мэ на ладжьяв-пэ, кэ сом ром)

It is thanks to the vanishing of this tradition in reality that the Gypsies can place it within the Gadjos' tradition of wandering. Cvetkov's approach to this topic is quite similar to Rajko Djurić's: “...The Gypsy as a human is not free yet and he hasn't found his home yet. In this sense, I guess, the Gypsy

the new life, /And I won't turn from Lenin's way". The appearance of the word Gadjo slightly ruins the didactic pathos of the poem. It demonstrates that the division Rom/Gadjo hasn't disappeared from the Gypsy consciousness, and living in houses still feels like the Gadjo life.

38 I'm not ashamed that I'm a Gypsy/My wagon flies on the road/We live like the birds... 
destiny and human destiny are variations of the same destiny" (Джурич 1999). The reader can't strictly identify the time borders of Cvetkov's stories and poetry. In the poem Poмa written in Russian, he places Gypsy wandering in the realm of dreams:

Во сне дороги - словно реки... ${ }^{39}$

Но им хотелось тяжесть будней забыть в своих тревожных снах... ${ }^{40}$

This meaning of a dream, of unconscious (and subconscious) motion:

Цыган и сам не замечает, какой дорогой он идет... ${ }^{41}$

- puts the Gypsy nomadic life in the sphere of archetypes, and this interpretation of the image of the road is also present in other works by Cvetkov.

To show the realization of this approach in Cvetkov's prose, I chose one of his short stories from the selected works Песня длиною в жизнь... ${ }^{42}$ (Цветков 2001) - Лана. This story was written in Russian and translated by the author into the Lovari and Russian Gypsy dialects. ${ }^{43}$ Here I use the translation in Russian Gypsy.

In the beginning of the story there appears the image of the sun, which is identified with the wheel of a Gypsy horse-drawn wagon. This metaphor introduces a sense of sacrum and profanum into the text (and into all of Cvetkov's works in fact). Just like all archetypes, the image of the sun-wheel is ambiguous:

Roma rakirna, so kham dykhela pe syr rota, khameskiri rota prastal piro boyben taj del dzhiipe sarenge. Ne koli jov xolyasola - sxachkorla sa so si dzhuvindo pro pkhuv ${ }^{44}$.

Thus, with the help of this comparison to the Gypsy wheel, the double meaning of the image of the sun (life, wandering versus death) transfers this ambivalence to Gypsy life and its nomadic foundations. The Gypsy girl Lana saves the kid and herself dies under the wheels of the drunken Gadjo's vehicle - the author shows the cruelty of life towards the Gypsies, who are guilty themselves even in their own death:

\footnotetext{
39 The roads are like the rivers in a dream.

40 They wanted to forget the heaviness of everyday routine in their anxious dreams.

41 The Gypsy isn't aware what road he walks...

42 A Song Long As Life

${ }^{43}$ This translation is accessible only on the Internet (all in Latin alfabet). That is one of the latest tendencies in Gypsy literature which appeared after 1938: it is written in Russian, and this is one of the threats to the Gypsy identity (Деметер... 2000: 242-243).

44 The Gypsies say that the sun looks like a wheel, the sun wheel [wandering] in the sky and giving life to everything. But if it was angry, it would destroy all life on the earth.
} 
Javne xalade (policija), lyne te golden po Roma: "So achade po drom chavores?!" Rom angil gadzhende sys doshalo tay avela ${ }^{45}$.

But at the same time the Gypsy wandering (as the sun wanders) is, just like the sun, the source of life and resurrection. Lana is resurrected in the narrator's dream, which is rich in mythological and literary allusions:

Progene bersha, koli ame yaviam po shteto kay sys garady Lana. Dre odoya rat me dykhtyiom la dro suno: yoy akharelas man pal peste. Koli me lyiom la palovast later kerdya pe drevo ${ }^{46}$.

Wandering is eternal life for Lana, and a metaphor for the eternal existence of the Gypsy people, Gypsy mentality:

Dykhtyom syr yoy lydzhala peskier vasta ko kham, polyiom so sa Romane chaya sy nabut Lana ${ }^{47}$.

Lana is the embodiment of Gypsy anima. The Gypsy nomadic life of the past is shown in Cvetkov's works as a half-forgotten dream, as an archetypal image - and that is why it's so important for the modern Gypsy cultural identity. Gypsy wandering is not a reality anymore, it has transformed into pure imagination, which has had an even greater influence on the Gypsy mentality.

Another example of philosophical reflection on the Gypsy mentality is found in Valdemar Kalinin's poetry. The special feature of his poems is a sentimental feeling for home, longing for the native place, which seems quite unusual for the Gypsy system of values at first sight. But, firstly, in this way the motif of identifying the Gypsy destiny with all of human destiny resounds more clearly in Kalinin's works. As already demonstrated in the analysis of Cvetkov's works, wandering is presented as a metaphor of human life, and in Kalinin's poetry it gains an additional shade - as a symbol of passing time (also involving literary allusions):

На прогыём мэ паш-дром,

Палэ дыкхав-пэ, рисёвав палал... (Мирэ штэтоскэ) $)^{48}$

\footnotetext{
45 The soldiers (the police) came, started to shout: "Why did you leave the kid on the road?!" It's always the Gypsy who is guilty, according to the Gadjo.

46 Years had passed when we appeared in the place where Lana was buried. That night I saw her in a dream: she called me to her. When I stretched out my hand to her, she turned into a tree.

47 I saw how she [a Gypsy girl] stretched her hands out to the sun, and I realized that every Gypsy girl had a little of Lana in her.

48 I haven't passed half of the way,/I look behind, I turn back... (To My Place)
} 
Secondly, the image of home in Kalinin's poems is always connected with the image of oblivion and dreaming: Сыр дадывэс душло амаро кхэроро...Сыр дэ суно... (Мирэ иттэтоскэ) ${ }^{49}$.

Home for the Gypsy is a place which can exist only in his recollection, or rather, in his imagination. It is an imaginary home, but the role of the imagination in forming and explaining the Gypsy mentality is very important for the modern Gypsy narrator.

Wandering is a source of recalling for the Gypsies - they pass by, but keep everything in their memory, as opposed to the settled Gadjo people who will inevitably forget their native place and their old parents:

Сыг до гав хасёла,

Екхджиныпэн и дар пхурэндэ дро якха,

Лэн бистырдэ сарэ, утрадынэ дро форо,

Рома ж лэн на бистрэна - да пуранэ мала. (Бистырдогав) ${ }^{50}$.

To Kalinin, having roots does not mean to live a settled life in one place. According to his poetical philosophy, the real roots for a human are the roots within life, and it is a connection to life that helps the Gypsies to continue and to gain their own memories. That is why in his poem he compares the Gypsies to the lime tree ${ }^{51}$. The tree, a traditional symbol of permanency and immutability, gains a new meaning - the meaning of hardiness, because of its strong connection with life itself - just like a Gypsy:

Талано романо дыкхава дрэ да липа

Дро шыл, бришынд баро хачькирипэ (Липа пашыл Асиновско дром) $)^{52}$.

Thus, the concept of the road has changed completely in modern Gypsy literature, gaining a new poetic dimension. Regarding this image, examples from Soviet and Russian Gypsy prose and poetry have demonstrated how the reconstruction of Gypsy identity in this literature has been changing as well. Soviet Gypsy literature developed within socialist realism and under ideological pressure, and that caused its ideological tendentiousness. The

49 As now I can see our little house...As if in a dream... (To My Place).

50 Soon [it] will disappear in the village,/ There is loneliness and fear in the old women's eyes,/ Everybody forgot them, went to town,/ the Gypsies won't forget them - the old friends (The Forgotten Village).

51 The Gypsy's traditional connection to the earth is also emphasized by scholars: “...Romano Chavo has a very strong feeling of reality... even if his head is in the clouds, his feet stay firmly on our planet, on the earth, to which he feels linked like a peasant, but for a different reason" (de Gila 2003: 63).

52 I, lucky Gypsy, look at the lime - /In cold, in huge rain it's warm (A Lime Tree By the Asinov Road). 
communist regime tried to transform the Gypsy vagrant mentality, and used Soviet Gypsy literature for this purpose as an ideological weapon. Nevertheless, these controversial features of Gypsy literature of the 1920s and 1930s do not make this literature less valuable. It was the first possibility for the Gypsy intelligentsia to speak about their people, their traditions and how they saw their future. Its realistic approach (inherited from classic Russian literature) creates a vivid image of the traditional Gypsy mentality, which is now at the centre of attention among Gypsy authors. Modern Gypsy literature is free of ideological control by the Russian majority. It exists in the cross-cultural context of Russian and world literature (Смирнова-Сеславинская 2009). The road as an archetypal image is a fundamental element of the reconstruction of Gypsy identity in modern Gypsy poetry and fiction. At the same time, Gypsy authors interpret the Gypsy road in a philosophical and poetical way, as a link uniting the Gypsies with other people on the earth. In this way, they break the borders of the traditional Gypsy division Rom/Gadjo, and the image of the road becomes important in the reconstruction of this new identity. Thus, this concept has always been a crucial one in Gypsy literature and, being an "eternal image", it has not exhausted its artistic potential yet.

\section{References}

Безлюдско Михаил (1931). Штар пшала, in: Алманахо романэ поэтэн, Москва, pp. 18-21 <http://www.liloro.ru/library/bezludsko1.htm> (accessed: 2013-02-13).

Цветков Георгий (2001). Лана, in: Песня длиною в жизнь..., Москва, pp. 31-34 $<$ http://www.gypsy-life.net/literatura04.htm> (accessed: 2013-02-13).

Цветков Георгий Поэзия <http://www.gypsy-life.net/literatura06.htm> (accessed: 2013-02-13).

Ильинско Михаил (1938). Бори, in: Роспхэныбэна тэ патриня, Москва, pp. 40-56 <http://www.liloro.ru/library/ilyinsko3.htm> (accessed: 2013-02-13).

Ильинско Михаил (1938). Бурда, in: Роспхэныбэна тэ патриня, Москва, pp. 5-19 <http://www.liloro.ru/library/ilyinsko1.htm> (accessed: 2013-02-13).

Ильинско Михаил (1938). Ружэнька, in: Роспхэнььбна тэ патриня, Москва, pp.20-39 <http://www.liloro.ru/library/ilyinsko2.htm> (accessed: 2013-02-13).

Калинин Вальдемар (2005). Романэ сунэ <http://www.gypsy-life.net/literatura14. htm> (accessed: 2013-02-13).

Бессонов Николай (2002). Цыгане: годы ссылок и побегов, in: 30 октября 26 <http:// www.liloro.ru/romanes/bessonov3.htm> (accessed: 2013-02-13).

Гугнин Александр (1995). Магический реализм и социалистический реализм (Несколько тезисов для сопоставительных исследований), іп: Наталия Куренная (еd.), Знакомый незнакомеи. Социалистический реализм как историко-культурная проблема. Москва: 76-90.

Деметер Нина, Бессонов Николай, Кутенков Владимир (2000). История цызан новый взгляд. Воронеж. 
Джурич Райко (1999). Цыганская литература, in: Lacio Drom 35, pp. 4-10 <http:// kulturom.ru/publicatios_of_literature.html> (accessed: 2013-02-13).

Калинин Вальдемар, Русаков Александр (2004). Обзор иыланской титературы бывшего Советского союза, стран СНГ и Балтии <http:/gypsy-life.net/ literatura13.htm $>$ (accessed: 2013-02-13).

Ковачази Сесил (2009). Поемите в проза в цыьганската литература като сплит на устната традиция и писменыя канон <http://www.kulturom.ru/literature. html> (accessed: 2013-02-13).

Куренная Наталия (1995). О социалистическом реализме, in: Наталия Куренная (ed.), Знакомый незнакомеи. Социалистический реализм как историкокультурная проблема. Москва: 5-10.

Махотина Илона (2008). О чем поёт цыганская «дочка-пташка»? (заимствованный балладный сюжет в фольклоре русских иылан), in: A.M. Смирнов-Кутачевский: тичность и научное наследие, Тверь: 299-319; $<$ http://www.liloro.ru/romano.htm> (accessed: 2013-02-13).

Махотина Илона (2012). Цьгане и русская культура. Тверь <http://cheloveknauka. com/tsygane-i-russkaya-kultura> (accessed: 2013-02-13).

Осьмухина Ольга (2007). «Сказ», in: Знание. Понимание. Умение 4: 236-237.

Ром-Лебедев Иван (1990). От иъьганского хора к театру «Ромен». Москва.

Смирнова-Сеславинская Мариана (2009). «Внутреннее», «внешнее» и «настоящее и,ьганское» в титературных публикаииях изыганских авторов, іп: Андрал 56-57: 49-69; <http://kulturom.ru/publicatios_of_literature.html> (accessed: 2013-02-13).

Щукин Василий (1993). «Путь» как познание и освобождение. К тематике nутешествия врусскойлитературе, in:Podróżwliteraturze rosyjskiej i winnych literaturach słowiańskich. Międzynarodowa Konferencja Literaturoznawcza Slawistów. Opole: 25-28.

Banaszkiewicz Magdalena (2008). "Obywatele Cyganie” - Rozmowa w Federacji Rosyjskiej. Historia, współczesność, przyszłość, in: T. Paleczny, J. TalewiczKwiatkowska (eds.). Tożsamość kulturowa Romów w procesach globalizacji. Kraków: 147-163.

Barany Zoltan (2002). The East European Gypsies. Regime Change, Marginality, and Ethnopolitics. Cambridge.

De Gila Vania (2003). Mówmy po romsku. Historia, kultura i język narodu romskiego. Szczecinek.

Głowiński Michał (1992). Rytuał i demagogia. 13 szkiców o sztuce zdegradowanej. Warszawa.

Lubecka Anna (2005). Bergitka Roma: tożsamość kulturowa. Kraków.

Nowicka-Rusek Ewa (2008). "Tradycyjna kultura Romów - kapitał kulturowy czy obciążenie”, in: T. Paleczny, J. Talewicz-Kwiatkowska (eds.). Tożsamość kulturowa Romów w procesach globalizacji. Kraków: 33-43.

Thompson Ewa (2000). Imperial Knowledge. Russian Literature and Colonialism. Connecticut-London. 


\section{„Ay, But Droma Pkhirdyom”: Cygan i droga \\ (Tożsamość własna w radzieckiej i postradzieckiej literaturze cygańskiej w rosyjskim kontekście kulturowym i politycznym)}

Cyganie zawsze byli szczególną mniejszością w Rosji. Z jednej strony Rosjanie podziwiali bezdomność Cyganów i ich pragnienie wolności. Cyganie stanowili swego rodzaju alter ego Rosjan: byli tacy, jakimi ci ostatni być chcieli, ale nie ośmielali się. Z drugiej zaś nawet w stosunkowo liberalnych czasach caratu traktowano ich jako ludzi drugiej kategorii, nie wspominając o sowieckich deportacjach. Wędrowny Cygan denerwował szczególnie, tak więc władze zawsze starały się ich osiedlać. Postawy Cyganów także były dwuznaczne (ścisła opozycja Gadziowie/Romi i jednocześnie zjawisko „chorału” osiadłych Cyganów, łączącego kultury rosyjską i cygańską). Ujawnia to główną cechę tożsamości cygańskiej: pragnienie ruchliwości, zależność - ale tylko w drodze, co zderzało się z dwoistą postawą rosyjskiej większości. Ową cechę jak też dwuznaczną postawę wobec niej można uznać za zasadniczy rys radzieckiej i postradzieckiej literatury cygańskiej. Około 1938 roku (zanim skończyło się wspieranie mniejszości narodowych) w radzieckiej literaturze cygańskiej występowały dwie główne linie narracyjne: narracja o złej kapitalistycznej przeszłości (wykorzystywanie „chorałowych” Cyganów, którzy zostali wyprowadzeni z drogi przez Rosjan: M. Iljinsko) oraz opisywanie wspaniałej rzeczywistości radzieckiej - kiedy to szczęśliwi Cyganie pracują i osiedlani są w kołchozach (M. Bezludzko). Taki obraz nowego radzieckiego Cygana ma źródła w obrazie bezdomności (ze względu na negowanie epoki radzieckiej i gloryfikację czasów carskich), co pokazuje szczegółowa analiza tekstów.

\section{„Ай, бут дрома пхирдём”: цыган и дорога \\ (самоидентификация в советской и постсоветской цыганской литературе в российском культурном и политическом контексте)}

Цыгане всегда были особым национальным меньшинством России. С одной стороны, русские восхищались свободолюбием и вольным образом жизни цыган. Цыгане были альтер-эго русских. С другой стороны, даже в относительно либеральную дореволюционную эпоху цыгане воспринимались как люди второго сорта (не говоря уже о гонениях, которым их подвергли в 


\section{| Maria Kuglerova}

советские времена). Особенно раздражало цыганское бродяжничество, и власти постоянно предпринимали попытки сделать цыган оседлыми. Реакция цыган была также амбивалетной: традиционное четкое разделение гаджё/ром и в то же время появление хоровых оседлых цыган, совмещающих русскую и цыганскую культуры. Основная черта цыганской идентичности - кочевая страсть, своего рода зависимость от дороги.

Эта особенность и двойственное отношение к ней являются решаюшими для советской и постсоветской цыганской литературы. До 1938 года (пока не прекратилась официальная поддержка культур меньшинств) в советской цыганской литературе сушествовали две основные тенденции: повествование о проклятом капиталистическом прошлом (эксплуатация хоровых цыган, «совращенных» с дороги русскими барами - рассказы М. Ильинского) и повествование о новой советской реальности - цыгане обретают счастье оседлой жизни, работая в колхозе (поэмы М. Безлюдского). Однако этот образ нового советского цыгана укоренен в кочевой жизни (посредством ее отрицания в изображении советской эпохи и прославления во царские времена), что показывает детальный анализ текстов.

С 1938 года и до распада СССР цыганская литература выходила в основном на русском языке. После 1991 года она стала возрождаться, и падение идеологических и цензурных барьеров отразилось на образе дороги как неотъемлемой части цыганской идентичности в современной цыганской прозе и поэзии (Г.Цветков, В.Калинин). Русский культурный контекст в этой новой литературе утрачивает свое первоначальное доминирующее влияние, и русская и цыганская культуры сосушествуют в ней на равных. 